\title{
EVALUASI IMPLEMENTASI HASIL DIKLAT TEKNIS GURU IPA MADRASAH TSANAWIYAH
}

\section{EVALUATION OF THE IMPLEMENTATION OF THE RESULTS OF THE IPA's TEACHERS OF MADRASAH TSANAWIYAH}

\author{
Umul Hidayati \\ Puslitbang Pendidikan Agama dan Keagamaan, Badan Litbang dan Diklat Kementerian Agama \\ email: hidayatikuncoro@yahoo.com
}

Naskah Diterima: 11 Maret 2020; Direvisi: 05 Mei 2020; Disetujui: 13 Agustus 2020

\begin{abstract}
The research entitled Implementation Evaluation of the Results of the 2019 Tsanawiyah Madrasah Teacher Training was conducted in 10 BDK regions. The results showed that after the training, teachers experienced a very high increase in competence, obtaining scores above 80. Generally, science teachers, alumni of education, and training felt that after attending the training, there is an increase in incompetence in terms of knowledge, skills, and attitudes. Among the three competency supporting variables, the attitude variable has the highest contribution, followed by the knowledge and skills variables. The increase in the high competence of science teachers after attending this training was observed by their ability to implement them in learning. However, the results of this training have not had a significant impact on improving the quality of madrasas, because, in most madrasas, the results of training are still challenging to implement due to many factors, including unavailability of laboratory facilities, the uneven ability of science teachers both in learning and in utilization. science equipment, the number of science teachers who have received training is still very few, and madrasah policies that do not support science learning.
\end{abstract}

Keywords: Evaluation; Implementation; Results of technical training; IPA's teacher at Madrasah Tsanawiyah

\begin{abstract}
Abstrak
Penelitian berjudul Evaluasi Implementasi Hasil Diklat Teknis Guru Madrasah Tsanawiyah Tahun 2019 yang dilakukan di 10 wilayah BDK, hasilnya menunjukkan bahwa pasca diklat guru mengalami peningkatan kompetensi sangat tinggi, dengan memperoleh skor di atas 80. Umumnya para guru IPA alumni diklat merasakan bahwa setelah mengikuti diklat, ada peningkatan kompetensi baik dari sisi pengetahuan, keterampilan dan sikap. Diantara ketiga variabel pendukung kompetensi tersebut, variabel sikap mempunyai kontribusi tertinggi, disusul variabel pengetahuan dan keterampilan. Peningkatan kompetensi guru IPA yang tinggi setelah mengikuti diklat ini sebenarnya juga diikuti oleh kemampuannya mengimplementasikan dalam pembelajaran. Namun demikian, hasil diklat ini belum berdampak signifikan dalam meningkatkan mutu madrasah, karena pada sebagian besar madrasah, hasil diklat masih sulit diimplementasikan karena terkendala banyak faktor antara lain: sarana laboratorium yang belum tersedia, kemampuan guru IPA yang belum merata baik dalam pembelajaran maupun dalam pemanfaatan peralatan IPA, jumlah guru IPA yang pernah memperoleh diklat masih sangat sedikit, dan kebijakan madrasah yang kurang mendukung terhadap pembelajaran IPA.
\end{abstract}

Kata Kunci: Evaluasi; Implementasi; Hasil diklat teknis; Guru IPA Madrasah Tsanawiyah 


\section{PENDAHULUAN}

Guru adalah pendidik profesional dengan tugas utama mendidik, mengajar, membimbing, mengarahkan, melatih, menilai, dan mengevaluasi peserta didik pada pendidikan anak usia dini jalur pendidikan formal, pendidikan dasar, dan pendidikan menengah, (Sesneg, 2017). Guru juga merupakan tenaga profesional yang bertugas merencanakan dan melaksanakan proses pembelajaran, menilai hasil pembelajaran, melakukan pembimbingan dan pelatihan serta melakukan penelitian (Indonesia, 2003). Sementara menurut Mukhtar \& Martinis Yamin (2008), keberhasilan belajar ditentukan oleh guru, sebab guru berperan dalam transformasi pengetahuan, keterampilan dan pemandu proses pembelajaran. Dari uraian ini dapat dipahami bahwa guru memiliki peran sangat penting sebagai pengajar, pendidik, pelatih, pembimbing, penasihat, penilai, dan pemandu proses pembelajaran. Melihat pada perannya tersebut, guru dituntut memiliki pengetahuan, keterampilan, dan sikap yang baik, dalam melaksanakan tugas mengajar.

Tuntutan terhadap guru tersebut nampaknya masih sulit terpenuhi, karena dalam kenyataan salah satu masalah besar yang dihadapi lembaga pendidikan di Indonesia termasuk MTs hingga saat ini adalah profesionalisme guru yang belum memadai, yang disebabkan kualifikasi dan kompetensi guru yang belum terpenuhi, sehingga masih banyak guru yang mengajar tidak sesuai bidang keahliannya (mismatch). Dalam Statistik Pendidikan Islam diketahui jumlah guru MTs sebanyak 299.360 orang, dengan kondisi $16,61 \%$ berpendidikan di bawah $\mathrm{S} 1$, dan $13 \%$ merupakan guru IPA, 23\% guru matematika, $31 \%$ guru Bahasa Inggris, 20\% guru Bahasa Indonesia, 39\% guru PKN, $18 \%$ guru PAI, dan $24 \%$ guru ilmu sosial, serta sebagian belum linier (mismatch) dalam mengajar (Kemenag, 2016). Di samping itu, masih banyak guru yang tidak mampu mengelola kelas dengan baik, kurang menguasai materi pembelajaran, kurang memahami regulasi di bidang pendidikan, miskin kreativitas dan inovasi, dan tingkat kedisiplinan rendah. Menurut Aisya Maura (2018), terdapat empat penyebab rendahnya kualitas guru di Indonesia yaitu: tidak sesuainya bidang ilmu dengan bidang mengajar (mismatch); banyak yang belum berkualifikasi sarjana; program peningkatan keprofesionalan guru yang rendah; dan rekrutmen guru yang tidak efektif. sementara menurut Sudarman Danim (2002), salah satu ciri krisis pendidikan di Indonesia adalah guru belum mampu menunjukkan kinerja yang baik, karena belum sepenuhnya ditopang oleh kualifikasi dan kompetensi yang memadai.

Dalam upaya peningkatan kualitas guru madrasah, pemerintah (Kementerian Agama) telah melakukan berbagai upaya peningkatan profesionalisme guru diantaranya melalui beasiswa studi lanjutan untuk jenjang S1, S2 dan S3 dalam beberapa tahun terakhir dan melalui program pendidikan dan pelatihan (Diklat) teknis terhadap guru madrasah, yang dilakukan oleh Pusat Pendidikan dan Pelatihan (Pusdiklat) dan Balai Pendidikan dan Pelatihan Keagamaan (BDK). Penyelenggaraan diklat khususnya bagi guru MTs ini telah menghasilkan alumni yang banyak. Data guru MTs yang pernah mengikuti diklat di Pusdiklat dan BDK di Seluruh Indonesia mulai tahun 2014 hingga 2017 sebanyak 18.210 orang, dan 9,4\% diantaranya adalah guru mapel IPA (Simdiklat Kemenag, 2014-2017).

Banyaknya volume penyelenggaraan diklat teknis bagi guru IPA MTs oleh Pusdiklat dan BDK ini, seharusnya sudah mampu meningkatkan kualitas pembelajaran di MTs dan menghasilkan hasil yang juga berkualitas. Idealnya sebuah diklat teknis mampu menghasilkan tenaga-tenaga yang kompeten, memiliki sikap profesional dan keterampilan yang lebih baik dari sebelum mengikuti diklat. Namun dalam kenyataan, penyelenggaraan diklat teknis tidak selamanya mencapai hasil sesuai harapan. Menurut Ira Meutya (2016), penyelenggaraan diklat teknis (termasuk diklat guru) terkadang hanya menjadi ajang berkumpul dan wahana hiburan sesaat bagi para pesertanya tanpa menyadari bahwa ada hal yang sangat penting yang terlewatkan oleh mereka, yaitu menjadi individu yang meningkat kompetensinya. Banyak faktor yang mempengaruhi ketidakberhasilan ini, antara lain: 1) tidak sejalannya tujuan dengan pelaksanaan diklat, dimana jumlah jam pelajaran (JP) untuk materi praktik tidak sesuai dengan kebutuhan (hanya diikuti sebagian kecil 
peserta); 2) rendahnya keterampilan narasumber dalam pengelolaan kelas, sehingga peserta kurang dapat menikmati sajian materi; 3) peserta diklat tidak sesuai kriteria yang ditetapkan, sehingga ilmu yang didapat dalam diklat menjadi sia-sia.

Abdul Haris Pito (2017), dalam artikelnya berjudul Permasalahan Diklat Teknis dan Solusinya menyatakan bahwa beberapa faktor penyebab diklat teknis gagal antara lain: 1) desain diklat tidak sesuai kebutuhan lembaga;

2) lemahnya penguasaan widyaiswara terhadap media dan metode pembelajaran; 3) sulitnya mengimplementasikan materi yang diterima peserta diklat karena terkendala minimnya sarana prasarana; 4) rendahnya mutu alat evaluasi hasil belajar yang disusun widyaiswara.

Melihat pada tingginya volume penyelenggaraan diklat teknis bagi guru IPA, dan melihat pada banyaknya faktor penyebab kegagalan diklat teknis dalam meningkatkan kinerja guru saat kembali ke lingkungan kerjanya, tahun 2017 Puslitbang Pendidikan Agama dan Keagamaan melakukan penelitian Evaluasi Implementasi Hasil Diklat Teknis Guru IPA MTs. Adapun tujuannya adalah untuk mengetahui implementasi hasil diklat teknis guru mata pelajaran (mapel) IPA MTs, yakni untuk melihat kinerja guru dalam melaksanakan tugas mengajar pasca mengikuti diklat, apakah terjadi perubahan dalam hal pengetahuan, keterampilan, dan sikap. Penelitian ini sangat penting dilakukan, karena salah satu tujuan diselenggarakannya diklat teknis bagi guru IPA adalah untuk meningkatkan kompetensi guru mencakup tiga ranah tersebut.

\section{KAJIAN TEORI}

Menurut Suharsimi Arikunto dan Safrudin Abdul Jabar (2009), evaluasi adalah serangkaian kegiatan yang ditujukan untuk menilai atau mengukur keberhasilan program pendidikan. Sedangkan menurut Sukardi (2014), evaluasi adalah suatu proses mencari data atau informasi tentang objek atau subjek yang digunakan untuk tujuan pengambilan keputusan terhadap objek atau subjek tersebut, atau menilai tingkat keberhasilan program tertentu. Sementara Menurut Safari (2011), evaluasi adalah serangkaian kegiatan yang ditujukan untuk mengetahui apakah suatu program telah berhasil dan efisien serta efektif atau tidak. Menurut Iriani Ismail (2010), evaluasi merupakan kegiatan mengumpulkan informasi yang digunakan untuk mengukur ketercapaian suatu program kegiatan dengan membandingkan dengan standar tujuan awal program. Begitu juga menurut Hadi (2011), evaluasi adalah suatu proses mengumpulkan informasi dan menilai suatu objek, kemudian membandingkan objek tersebut dengan kriteria, standar dan indikator.

Dari pengertian oleh beberapa pakar tersebut, dapat disimpulkan bahwa evaluasi adalah suatu proses kegiatan yang sistematis yang ditujukan untuk mengukur keberhasilan suatu program/kegiatan dengan mengumpulkan informasi dan menilai suatu objek (sasaran evaluasi) serta menilai tentang bekerjanya sesuatu, yang hasilnya dapat dijadikan alternatif dalam mengambil keputusan.

Dalam kaitannya dengan diklat, maka evaluasi yang dimaksud adalah evaluasi terhadap penyelenggaraan diklat, yang mencakup perencanaan, pelaksanaan dan hasil. Sehingga evaluasi diklat pada intinya bertujuan mengukur keberhasilan program diklat dalam segi kualitas penyelenggaraan program mencakup aspek teknis dan substantif, serta hasil belajar peserta diklat yang dibuktikan dengan adanya peningkatan pengetahuan, ketrampilan, dan sikap, yang disingkat ksa atau sering juga disebut kompetensi. Namun dalam kegiatan evaluasi ini, membatasi pada evaluasi hasil diklat khususnya untuk melihat bagaimana implementasi hasil diklat teknis pasca program diklat diselenggarakan. Karena menurut Adi Wijaya dan Sumarno (2017), keberhasilan suatu program diklat tidak hanya sekedar dilihat dari tercapainya jumlah sasaran, terselenggaranya diklat, dan berjalannya semua proses diklat sesuai dengan perencanaan, adanya peningkatan nilai pos tes terhadap nilai pretest, serta tercapainya kepuasan peserta, namun juga dapat dilihat dari bagaimana perubahan perilaku peserta diklat pasca mengikuti diklat.

Adapun dilihat dari jenisnya, menurut Dillan Azaly Al-Farozi (2015), jenis evaluasi diklat bermacam-macam antara lain pretest, formatif, sumatif, plan of action participant atau rencana kegiatan peserta, evaluasi diri, 
evaluasi terhadap instruktur, evaluasi terhadap program diklat dan evaluasi pasca program diklat, evaluasi diklat memang dapat dilakukan secara menyeluruh terhadap penyelenggaraan diklat semenjak awal perencanaan, pelaksanaan, hingga akhir bahkan pasca program diklat. Namun, evaluasi diklat dapat juga dilakukan pada momen-momen tertentu, karena adanya kepentingan-kepentingan dan tujuan tertentu.

Terkait dengan kegiatan ini, maka evaluasi diklat yang dilakukan adalah evaluasi pasca diklat untuk melihat implementasi hasil diklat guru IPA MTs di tempat kerjanya, apakah ada perubahan kinerja guru IPA tersebut dalam mengajar pasca mengikuti diklat dalam hal pengetahuannya, keterampilan, dan sikap.

Untuk melakukan evaluasi diklat, banyak model evaluasi yang dikembangkan oleh para ahli, antara lain model empat level oleh Donald L. Kirkpatrick Thun 1998, model lima level/model ROI oleh Jack PhillPS, Model CIPP oleh Stufflebeam dan masih banyak lagi model lainnya. Namun dalam kegiatan ini, model evaluasi yang digunakan adalah model Kirkpatrick, yang memperkenalkan evaluasi dengan model empat level atau The four levels. Menurut Donald L., Kirkpatrick (1998), model empat level adalah model evaluasi diklat dengan membuat kategori hasil diklat menjadi empat level yaitu level reaksi, pembelajaran, perilaku, dan hasil.

Level 1 reaksi, yaitu mengukur bagaimana tingkat kepuasan peserta diklat. Apabila diklat dapat memuaskan peserta, maka mereka tertarik dan termotivasi untuk belajar dan berlatih. Tahap evaluasi ini, dilakukan segera setelah pelatihan selesai diberikan, dan paling mudah dilakukan dengan check list. Halhal yang dievaluasi, yaitu materi pelatihan, metode pelatihan, logistik, dan narasumber.

Level 2 pembelajaran, yaitu mengukur kemampuan peserta diklat dalam menerima kegiatan pembelajaran, mencakup aspek pengetahuan, keterampilan dan sikap. Evaluasi ini dilakukan ketika diklat masih berlangsung, yakni pada jam terakhir pelatihan. Tujuannya untuk mengukur tingkat pemahaman peserta atas materi pelatihan yang diberikan. Evaluasi dilakukan melalui tes tertulis, studi kasus pada peserta diklat, simulasi, role play dan presentasi materi yang telah dipelajari oleh peserta.

Level 3 perilaku, yaitu mengukur perubahan perilaku peserta diklat setelah mengikuti diklat di tempat kerjanya, dengan melihat pada perubahan/peningkatan pengetahuan, ketrampilan dan sikap. Ini berarti mengukur implementasi hasil diklat oleh peserta diklat dalam pekerjaan sehari-hari.

Level 4 hasil,yaitu mengukur hasil akhir yang diperoleh peserta diklat setelah mengikuti diklat atau dampak diklat terhadap organisasi. Beberapa aspek yang diukur adalah: 1) Tangible, mencakup: a) hasil kerja; c) waktu kerja; d) kualitas kerja; c) biaya kerja; 2) Intangible, mencakup: a) kebiasaan kerja; b) iklim kerja; c) keterampilan; d) kepuasan; dan e) inisiatif. Dari empat level evaluasi Kirkpatrick tersebut, dalam kegiatan evaluasi ini hanya menggunakan 2 level saja yaitu level ke 3 perilaku dan level 4 hasil.

Implementasi adalah suatu tindakan atau pelaksanaan dari sebuah rencana yang sudah disusun secara matang dan terperinci. Implementasi biasanya dilakukan setelah perencanaan sudah dianggap matang atau sempurna. Menurut Agustino (2010), implementasi merupakan suatu proses yang dinamis, dimana pelaksana kebijakan melakukan suatu aktivitas atau kegiatan, sehingga pada akhirnya akan mendapatkan suatu hasil yang sesuai dengan tujuan atau sasaran kebijakan itu sendiri. Hal yang hampir sama disampaikan Grindle dalam Haedar Akib (2010), bahwa implementasi merupakan proses umum tindakan administratif pada program tertentu untuk mencapai tujuan. Menurut Ripley dan Franklin dalam Rohman, Hanafi \& Minto (2010), implementasi adalah kegiatan/tindakan yang dapat dilakukan setelah ditetapkannya undang-undang yang memberikan otoritas program, kebijakan, yang memberi keuntungan, atau suatu jenis keluaran yang nyata. Sedangkan menurut Gordon dalam T. Keban Yeremias (2008), implementasi merupakan tahapan dalam proses kebijakan publik berkenaan dengan berbagai kegiatan untuk merealisasikan program atau tahap merealisasikan tujuantujuan program. Begitu juga menurut Mulyadi (2015), implementasi mengacu pada tindakan 
untuk mencapai tujuan-tujuan yang telah ditetapkan dalam suatu keputusan program.

Dari beberapa pengertian tersebut secara singkat dapat disimpulkan bahwa implementasi adalah suatu proses/tahapan-tahapan kegiatan yang terencana dan dilakukan secara sungguhsungguh sebagai bentuk realisasi dari suatu program yang sudah ditetapkan/direncanakan secara matang sebelumnya, guna mencapai tujuan program tersebut. Dalam kaitannya dengan implementasi hasil diklat, maka implementasi yang dimaksud adalah suatu proses/tahapan kegiatan pembelajaran yang dilakukan oleh guru IPA MTS setelah mengikuti diklat, sebagai bentuk realisasi penerapan ilmu yang sudah diperoleh melalui program diklat, sejauh mana para guru tersebut telah mengalami perubahan atau peningkatan kompetensi. Terjadinya peningkatan kompetensi ini, berarti tujuan program diklat telah tercapai.

Menurut Kemenag (2012), diklat teknis adalah proses penyelenggaraan pendidikan dan pelatihan dalam rangka meningkatkan kompetensi teknis pegawai (PNS atau non PNS) di lingkungan kementerian agama (kemenag), mencakup pengetahuan, keterampilan, dan sikap, yang diperlukan untuk dapat melaksanakan tugas atau pekerjaan tertentu. Sehingga tujuan diklat teknis secara khusus adalah untuk meningkatkan kompetensi teknis PNS dan non PNS yang meliputi pengetahuan, keterampilan, dan sikap, agar sesuai dengan standar kompetensi teknis yang dibutuhkan oleh satuan organisasi atau jabatannya. Sedangkan secara umum adalah untuk meningkatkan kinerja organisasi tempat PNS atau non PNS melaksanakan tugasnya.

Pengetahuan dalam konteks pembelajaran adalah segala sesuatu yang harus diketahui oleh guru dalam pembelajaran. Menurut Sardiman (2011), guru harus memiliki dasar pengetahuan yang luas tentang: 1) tujuan pendidikan; 2) materi yang diajarkan; 3) cara mentransfer ilmu pengetahuan secara mudah dan efektif; 4) cara melakukan pembelajaran sesuai kebutuhan peserta didik; 5) karakteristik diri pribadi setiap siswa mencakup potensi, bakat dan minatnya dalam belajar; 6) cara menempatkan kedewasaannya, seperti menjadi teladan perilaku yang baik, terbuka, serta menghindari perbuatan tercela.
Dari penjelasan ini, dapat dipahami bahwa guru harus memiliki pengetahuan yang utuh dan baru mengenai ilmu yang diajarkan, tujuan pembelajaran, metode pembelajaran, dan karakteristik siswa, sehingga informasi yang disampaikan kepada siswa bukan informasi yang salah. Oleh karena itu guru harus selalu memperbaharui informasi, agar dapat mengikuti perubahan jaman.

Sedangkan keterampilan adalah kemampuan untuk menggunakan akal, fikiran, ide dan kreativitas dalam mengerjakan atau membuat sesuatu menjadi lebih bermakna dan bernilai. Menurut Tommy Suprapto (2009), keterampilan adalah kemampuan untuk menerjemahkan pengetahuan ke dalam praktik sehingga tercapai hasil kerja yang diinginkan. Menurut Soni Hendriani \& Soni A. Nulhaqim (2008), keterampilan adalah kemampuan mengoperasikan pekerjaan secara mudah dan cermat. Berkaitan dengan guru, keterampilan adalah kemampuan melaksanakan pembelajaran yang efektif dan efisien.

Menurut Turney (1973), keterampilan yang harus dimiliki guru dalam mengajar adalah: 1) Keterampilan bertanya dengan bahasa verbal untuk meminta respons siswa tentang pengetahuan atau sekedar mengembalikan konsentrasinya; keterampilan menjelaskan materi/informasi secara lisan dan obyektif; 3) Keterampilan memberikan penguatan atau umpan balik bagi siswa; 4) Keterampilan melakukan diversifikasi metode pembelajaran agar pembelajaran lebih menyenangkan; 5) Keterampilan mengelola kelas yang kondusif dan meminimalisir gangguan dalam pembelajaran; 6) Keterampilan menggunakan media/alat bantu dan sumber belajar; 7) Keterampilan melakukan evaluasi (menyusun instrumen, melaksanakan penilaian, dan melakukan analisis).

Secara umum, sikap adalah bentuk pernyataan seseorang terhadap hal-hal yang ditemuinya, seperti benda, orang, peristiwa ataupun fenomena. Menurut Syaifudin Azwar (2011) sikap adalah reaksi seseorang terhadap suatu objek dengan cara-cara tertentu, atau kesadaran individu untuk menentukan tingkah laku nyata dan perilaku yang mungkin terjadi. Sehingga sikap dapat menuntun perilaku seseorang untuk bertindak sesuai dengan sikap 
yang diekspresikan. Menurut Ngalim Purwanto, guru harus memiliki sikap: 1) jujur terhadap perkataan dan perbuatan; 2) disiplin dalam menjalankan tugas; 3 ) adil dan tidak pilih kasih terhadap siswa; 4) percaya dan menyayangi siswa; 5) sabar dan rela berkorban; 6) baik terhadap teman dan masyarakat; 7) suka memberikan nasihat dan motivasi kepada siswa agar tekun dalam belajar; dan 8) suka menolong. Sedangkan menurut Nana Sujana dalam Muhajir, sikap yang harus dimiliki guru adalah: 1) respek terhadap apa yang terjadi di sekitarnya; 2) antusias terhadap tugasnya; 3) menghargai pekerjaannya sebagai seorang guru; 4) mencintai mapel yang diajar; 5) toleransi terhadap sesama teman profesinya; dan 6) memiliki kemauan yang keras untuk meningkatkan hasil pekerjaannya. Beberapa penjelasan terkait dengan aspek-aspek pengetahuan, keterampilan dan sikap yang harus dimiliki seorang guru ini, menjadi kajian dalam melakukan evaluasi terhadap guru IPA pasca mengikuti diklat.

Peserta diklat teknis yang dievaluasi adalah guru IPA MTs yang pernah mengikuti diklat mapel IPA tahun 2014-2017 di Pusdiklat dan BDK. Dipilihnya guru mapel IPA dengan alasan karena mapel IPA merupakan salah satu titik lemah yang ada di madrasah selain matematika. Hal ini dapat dilihat dari hasil UN mapel IPA Tahun 2015, 2016 dan 2017 jenjang MTs, berada pada posisi terendah kedua setelah matematika. Alasan ini diperkuat oleh penelitian Fatimatu Zahrah tahun 2012 berjudul Problematika Guru IPA dalam Pembelajaran IPA Terpadu (Studi Kasus pada MTsS Matholibul Huda Mlonggo Jepara). hasilnya menunjukkan bahwa pada pelaksanaan pembelajaran IPA, guru masih kurang menguasai materi dan kesulitan menguasai kelas, namun sudah menggunakan metode yang tepat. Hasil penelitian Febri Rasmianti tahun 2015 berjudul Hambatan Guru dalam Pembelajaran IPA di SMP dan Sekolah Sederajat di Kecamatan Rambah Samo, menunjukkan bahwa pemahaman guru tentang laboratorium IPA masih rendah dengan skor $63 \%$.

Kompetensi adalah kecakapan seseorang ketika melakukan sesuatu. Menurut E. Mulyasa (2004), kemampuan adalah perpaduan dari keterampilan, nilai dan sikap, yang direfleksikan dalam kebiasaan berpikir dan bertindak. Sedangkan Gordon dalam Mulyasa (2004) menyatakan ranah kompetensi meliputi: 1) pengetahuan, 2) pemahaman, 3) keterampilan, 4) nilai, 5) sikap. Adapun dalam Peraturan Pemerintah Nomor 74 Tahun 2008 dan dalam Undang-Undang Nomor 14 Tahun 2005, disebutkan kompetensi adalah seperangkat pengetahuan, pemahaman, keterampilan, sikap, dan perilaku yang harus dimiliki, dihayati, dikuasai, dan diaktualisasikan oleh guru dan dosen dalam melaksanakan tugas.

Dari beberapa pengertian tersebut, maka kemampuan adalah seperangkat pengetahuan, keterampilan, sikap dan perilaku, yang dimiliki seseorang dalam melaksanakan tugasnya. Beberapa hal tersebut menjadi kajian dalam penelitian ini. Sedangkan yang dimaksud dengan kemampuan/ kompetensi guru pasca diklat adalah kemampuan yang dimiliki guru pasca mengikuti diklat mencakup pengetahuan, keterampilan, sikap, dan perilaku.

Beberapa penelitian evaluasi diklat oleh Puslitbang Pendidikan Agama dan Keagamaan antara lain: 3) Penelitian oleh Farida Hanun (2007) berjudul Evaluasi Penyelenggaraan Diklat Di Kementerian Agama, hasilnya antara lain bahwa komponen input program diklat ketercapaiannya rendah seperti terjadi nepotisme dalam rekrutmen peserta, widyaiswara kurang profesional, penyusunan kurikulum kurang melihat pada kebutuhan guru dan prasarana diklat kurang memadai. 2) penelitian yang dikoordinatori Ahmaduddin tahun 2015 berjudul Evaluasi Penyelenggaraan Diklat Teknis, hasilnya menunjukkan bahwa penyelenggaraan diklat teknis dilihat dari input, proses, output, dan outcome, masuk kategori cukup. 3) Qowaid (2012) dalam penelitiannya berjudul Evaluasi Diklat Jarak Jauh pada Balai Diklat Keagamaan Semarang, dengan mengevaluasi mata pelajaran Matematika dan Kimia untuk Guru Madrasah Tsanawiyah dan Madrasah Aliyah. 4) Penelitian Qowaid dan Neni Setianingsih (2006) tentang Evaluasi Diklat Guru Pendidikan Agama Islam Tingkat $S M A$, yang mengevaluasi terhadap diklat yang dilaksanakan oleh lembaga diklat yang berada di bawah Departemen Agama. 
Beberapa penelitian oleh pihak lain antara lain: 1) Penelitian Ratna Prilianti (2018) berjudul Evaluasi Penyelenggaraan Diklat Teknis Substantif Multimedia Bagi Guru Madrasah Aliyah Di Balai Diklat Keagamaan Semarang, hasilnya menunjukkan bahwa kepuasan peserta terhadap pelaksanaan diklat masuk kategori baik dengan skor pada aspek edukatif penyelenggaraan diklat 87,62 , aspek fasilitas 87,63, aspek pelayanan 89,38, dan aspek pengetahuan 82,07. 2) Penelitian Eva Riza (2014) berjudul Efektivitas Diklat Berjenjang tingkat Dasar Pendidik Dan Tenaga Kependidikan PAUD yang salah satu tujuannya melihat dampak diklat hasilnya menunjukkan bahwa dampak keikutsertaan peserta pada Diklat Tingkat Dasar secara keseluruhan meningkat, namun peningkatan hasil/dampak tersebut terhadap lembaga sangat tergantung dari motivasi internal dan eksternal serta kreativitas individu peserta Diklat. 3) penelitian oleh Cut N. Ummu Athiyah (2019) berjudul Evaluasi Program Diklat Unggulan Pusdiklat Tenaga Teknis Pendidikan Dan Keagamaan 2018 hasilnya bahwa secara umum Evaluasi Model CIPP Pada Implementasi Program Diklat Teknis Substantif UN Bahasa Inggris MA Pusdiklat Tenaga Teknis Pendidikan dan Keagamaan tahun 2018 telah berjalan dengan baik (sistematik, terencana, teratur, dan berkesinambungan), baik pada tahap konteks, input, proses, maupun produk. 4) Penelitian oleh mahasiswa Pasca Sarjana UI Agustina (2015) berjudul Evaluasi Program Diklat Teknis Fungsional Peningkatan Kompetensi Guru Muda MTs Mapel Bahasa Inggris dengan Menggunakan Model Countenance Stake, di Pusdiklat Medan, hasilnya menunjukkan bahwa diklat dapat dilaksanakan dengan baik dan mampu meningkatkan pengetahuan, keterampilan, dan sikap guru, karena didukung fasilitas yang memadai dan pemanggilan peserta sesuai mekanisme yang benar.

Dari beberapa hasil penelitian ini, maka Evaluasi Implementasi Hasil Diklat Teknis Guru MTS mapel IPA ini semakin menunjukkan relevansinya untuk dilakukan evaluasi lebih lanjut. Karena evaluasi terhadap hasil diklat/pasca diklat merupakan hal penting untuk mengetahui apakah diklat benar-benar mampu memberi manfaat signifikan dalam meningkatkan kompetensi guru pada aspek pengetahuan, keterampilan dan sikap.

\section{METODOLOGI}

Penelitian ini dilakukan menggunakan metode survei, dengan pendekatan mix method (kuantitatif, juga kualitatif). Teknik pengumpulan data dilakukan melalui penyebaran kuesioner kepada guru IPA MTs Alumni Diklat. Untuk memperdalam analisis, juga dilakukan wawancara terhadap responden yang dianggap penting seperti Kepala MTs dan guru IPA MTs, dan dilakukan studi dokumen dengan mengkaji beberapa dokumen penting yang ada kaitannya dengan penelitian ini. Penelitian dilakukan di 10 wilayah BDK yaitu Sumatera Utara, Sumatera Barat, Sumatera Selatan, DKI Jakarta, Jawa Barat, Jawa Tengah, Jawa Timur, Kalimantan Selatan, Bali, dan Sulawesi Selatan. Penetapan 10 wilayah ini dengan alasan karena kesepuluh BDK tersebut memiliki alumni diklat guru IPA MTS tahun 2014-2017 dengan jumlah banyak dan tidak menyebar di berbagai pulau.

Unit analisis penelitian ini adalah guru MTs yang pernah mengikuti diklat, sedangkan populasi penelitiannya adalah guru IPA MTs yang pernah mengikuti diklat di Pusdiklat dan BDK di 10 wilayah. Populasi samplingnya adalah seluruh guru IPA MTs yang pernah mengikuti diklat teknis tahun 2014-2017 di Pusdiklat dan BDK di 10 provinsi yang berjumlah 1522 orang. Penentuan besaran sampel penelitian, dilakukan menggunakan rumus Slovin dengan Margin of Error $(\mathrm{MoE})$ $6 \%$ dengan tingkat kepercayaan $94 \%$. Sedangkan penarikan sampelnya menggunakan teknik multi stage random sampling. Dengan teknik tersebut, diperoleh sampel sebanyak 235 orang responden penelitian terdiri dari guru MTs mapel IPA yang pernah ikut diklat.

\section{HASIL DAN PEMBAHASAN}

\section{Identitas Responden Guru IPA MTs Alumni Diklat}

Pengolahan dan analisis data ini dilakukan terhadap responden Guru IPA MTs Alumni Diklat sebanyak 235 orang (167 orang perempuan dan 69 orang laki-laki), dan terdiri dari 146 orang berusia antara 36-49 tahun, 48 orang berusia lebih dari 50 tahun, dan 42 orang 
berusia 35 tahun. Dilihat dari jenjang pendidikannya, sebanyak 186 orang berpendidikan S1, 47 orang S2, dan 7 orang D3/sarjana muda. Hal ini menunjukkan bahwa kondisi guru IPA MTs sudah memenuhi kualifikasi sesuai dengan Standar Nasional Pendidikan (SNP), namun belum maksimal, karena jumlah guru yang berpendidikan S2 masih sangat sedikit dan masih ada guru yang belum berpendidikan S1/sarjana. Belum maksimalnya pendidikan guru IPA MTs ini patut diduga kompetensi guru IPA tersebut juga belum maksimal. Sedangkan dilihat dari statusnya, sebanyak 201 orang berstatus PNS dan 35 orang non PNS. Tingginya jumlah PNS ini menunjukkan bahwa penyelenggaraan diklat teknis mapel IPA masih menjadi prioritas bagi guru PNS dan belum banyak menyentuh guru non PNS. Padahal realitasnya, guru non PNS jumlahnya jauh lebih banyak dibanding yang PNS. Jumlah guru MTs sebanyak 299.360 orang. Dari jumlah ini, sekitar $70 \%$ lebih merupakan Guru non PNS dan sekitar 13\% merupakan guru IPA (Kemenag, 2016).

Bagi guru PNS yang pernah mengikuti diklat, keikutsertaannya juga belum maksimal, karena sebagian besar guru (149 orang) baru mengikuti satu kali, 43 orang mengikuti dua kali, dan 44 orang 3 kali. Hasil ini menunjukkan bahwa volume penyelenggaraan diklat masih sangat sedikit, sehingga belum mampu merekrut jumlah peserta yang banyak dan merata bagi guru IPA MTs yang ada di seluruh wilayah BDK. Belum meratanya kesempatan diklat bagi guru IPA MTs ini, karena penyelenggaraan diklat selama ini belum menemukan sistem yang tepat, sehingga dalam penyelenggaraannya belum memiliki acuan yang jelas, yang tertib, dan terstruktur dengan baik. Menurut para guru peserta diklat, penyelenggaraan diklat teknis bagi guru IPA ini perlu ditingkatkan volumenya, agar seluruh guru IPA MTs memiliki kesempatan meningkatkan kompetensi melalui diklat, dan sekaligus dapat mewujudkan kebijakan Kepala Badan Litbang dan Diklat kala itu Prof. Dr. Atho Mudzhar, tentang penyelenggaraan diklat 4 tahun sekali bagi guru madrasah, sebagai upaya maintenance guru terhadap peningkatan kompetensinya, dan agar tidak kehilangan ghirohnya setelah sekian lama diklat berlangsung. 4 tahun merupakan waktu yang pas untuk maintenance kemampuan guru dalam mengajar pasca diklat.

Lama waktu penyelenggaraan diklat juga merupakan hal penting yang perlu dipertimbangkan. Menurut sebagian besar (110 orang) guru alumni diklat yang pernah mengikuti diklat 7-12 hari, merasa sudah mencukupi, asal waktu tersebut lebih banyak dialokasikan untuk penyampaian materi inti. Sebab jika banyak waktu yang dialokasikan untuk materi-materi penunjang yang sebenarnya tidak terlalu urgen, maka waktu tersebut dirasa kurang, dan para guru menyarankan lama waktu diklat ditambah lebih dari 12 hari, agar penyampaian materi lebih maksimal dan tujuan diklat tercapai. Ini seperti yang dirasakan oleh 57 orang guru IPA yang mengikuti diklat lebih dari 12 hari.

\section{Peningkatan Kompetensi Guru Pasca Diklat (Evaluasi Diri Guru IPA MTs Alumni Diklat)}

Kompetensi guru sebagai hasil diklat, dapat diukur melalui tiga indikator yaitu pengetahuan, keterampilan dan sikap. Hal ini selaras dengan tujuan diklat yaitu untuk meningkatkan pengetahuan, keterampilan, dan sikap, yang biasa disingkat KSA.

Variabel pengetahuan guru dalam pembelajaran IPA yang diukur melalui 12 indikator yaitu tujuan, materi, dan metode (pembelajaran IPA), cara mentransfer ilmu pengetahuan kepada siswa, cara mengenal karakteristik siswa, cara mengidentifikasi dan membantu mengembangkan potensi siswa, cara mengidentifikasi dan membantu menyalurkan minat dan bakat siswa, cara membimbing siswa dalam belajar kelompok, cara melakukan pembelajaran sesuai kebutuhan siswa, dan cara menjadi teladan yang baik bagi siswa, terlihat rerata skor peningkatan pengetahuan guru IPA MTs setelah mengikuti diklat adalah 79,49, atau masuk kategori baik/tinggi. Seluruh indikator tersebut telah berkontribusi dalam mendukung peningkatan pengetahuan dengan rerata skor peningkatan 76,27-82,71.

Sementara variabel keterampilan guru dalam pembelajaran IPA yang diukur melalui 21 indikator yaitu: mengenal karakteristik siswa, mengidentifikasi dan membantu menyalurkan bakat dan minat siswa, 
membimbing siswa dalam belajar kelompok, menjelaskan materi IPA secara lisan, bertanya kepada siswa sehabis pembelajaran, memberikan umpan balik kepada siswa, mengembangkan metode pembelajaran IPA yang bervariasi, menciptakan situasi pembelajaran yang menyenangkan, meminimalisir gangguan dalam pembelajaran, melakukan presentasi materi IPA, berkomunikasi secara lisan kepada siswa dalam pembelajaran, memanfaatkan media belajar IPA berbasis alam dan IT, menciptakan media belajar IPA dengan bahan bekas dan alam sekitar, memilih media belajar IPA yang tepat, melakukan pembelajaran praktikum IPA di alam sekitar dan di laboratorium, menyusun alat evaluasi dan melakukan evaluasi capaian hasil belajar serta menganalisis hasil evaluasi, hasilnya menunjukkan rerata skor peningkatan keterampilan guru setelah diklat adalah 78.09, atau masuk kategori baik/tinggi. Sebagian besar indikator tersebut telah berkontribusi dalam peningkatan keterampilan, dengan rerata skor peningkatan 74,13-83,05. Namun terdapat dua indikator yang paling rendah kontribusinya yaitu keterampilan memanfaatkan media belajar IPA berbasis IT dan melakukan pembelajaran praktikum IPA di laboratorium. Sehingga untuk dapat meningkatkan kompetensi guru secara maksimal, perlu dilakukan upaya-upaya peningkatan keterampilan pada kedua indikator tersebut.

Sedangkan variabel sikap guru dalam pembelajaran IPA yang diukur melalui 14 indikator yaitu: disiplin dalam melaksanakan tugas mengajar, jujur dalam perkataan dan perbuatan, adil dalam memberlakukan seluruh siswa, senang dan sayang terhadap seluruh siswa, sabar menghadapi berbagai perilaku siswa, ikhlas dan rela berkorban untuk keberhasilan siswa, semangat menjadi teladan kebaikan bagi siswa, semangat memotivasi belajar siswa, peduli dan toleransi terhadap sesama teman sejawat, respek terhadap kondisi lingkungan sekitar, senang terhadap mapel IPA, dan memiliki kemauan meningkatkan kualitas pembelajaran IPA, diketahui rerata skor peningkatan sikap guru setelah diklat adalah 83,15, dan masuk kategori baik/tinggi, dengan rentang rerata skor peningkatan antara 81,95-85,68. Hasil yang bagus pada variabel sikap ini, sehingga madrasah tidak mengalami beban yang terlalu berat untuk meningkatkan kompetensi guru dan tinggal memotivasi guru agar lebih semangat memperbaiki sikapnya dalam mengajar, karena pada dasarnya sikap guru sudah baik.

Hasil pengukuran melalui tiga variabel yaitu pengetahuan, keterampilan dan sikap, menunjukkan bahwa kompetensi guru IPA MTs setelah mengikuti diklat, mengalami peningkatan kompetensi sebesar 80,17 dan masuk kategori tinggi. Dari tiga variabel tersebut, variabel sikap merupakan variabel tertinggi dalam mendukung peningkatan kompetensi guru IPA dengan skor 83,17, disusul variabel pengetahuan dengan skor 79,43 dan variabel keterampilan dengan skor 78,12.

Hasil tersebut menunjukkan bahwa diklat teknis yang diselenggarakan di Pusdiklat dan BDK mempunyai peranan yang sangat penting dalam mendorong peningkatan kompetensi guru IPA MTs yang signifikan. Hal ini selaras dengan yang dikemukakan oleh Nana Sudjana (2006), bahwa hasil dari kegiatan pendidikan adalah kemampuan (kompetensi) yang dimiliki siswa (peserta diklat) setelah ia menerima pengalaman belajarnya (selama mengikuti diklat). Sedangkan menurut Wina Sanjaya (2009), hasil belajar berkaitan dengan pencapaian dalam memperoleh kemampuan sesuai dengan tujuan khusus yang direncanakan dalam pembelajaran. Dengan demikian peningkatan kompetensi yang dicapai para guru IPA MTs setelah mengikuti diklat adalah merupakan tujuan utama diselenggarakannya diklat.

Terkait dengan peningkatan kompetensi ini, Horward Kingsley dalam Nana Sudjana (2006) menyebutkan bahwa tiga kompetensi yang dapat dicapai dari hasil belajar yaitu keterampilan, pengetahuan, dan sikap. Ini sesuai dengan tujuan diklat teknis bagi guru yaitu untuk mencapai peningkatan pengetahuan, keterampilan, dan sikap. Menurut Gagne dalam Nana Sudjana (2009), ada lima kompetensi yang dapat dicapai dari hasil belajar yaitu pengetahuan/informasi verbal, strategi kognitif, keterampilan intelektual dan motoris, dan sikap. Sementara menurut Benyamin Bloom, capaian hasil belajar mencakup tiga ranah yaitu ranah kognitif, afektif, dan psikomotoris. Sedangkan menurut Yasri 
(2017), batasan evaluasi pasca diklat terhadap peningkatan kompetensi alumni peserta diklat adalah peningkatan kompetensi pedagogik, kompetensi keilmuan dan kompetensi profesional yang berkelanjutan.

Dari pendapat beberapa pakar ini, secara garis besar bahwa penyelenggaraan diklat teknis bagi guru setidaknya harus mampu menghasilkan peningkatan kompetensi guru mencakup tiga aspek yaitu peningkatan kompetensi pada ranah pengetahuan, keterampilan, dan sikap.

\section{Anilisis Data Peningkatan Kompetensi Guru IPA MTs}

Untuk mengetahui adanya pengaruh ketiga variabel yaitu pengetahuan, keterampilan dan sikap terhadap peningkatan kompetensi guru IPA MTs, diuji dengan Partial Least Square (PLS). Digunakannya analisis ini, karena ketiga variabel penelitian tersebut tidak dapat diukur secara langsung (bersifat laten). Kriteria hasil pengujian adalah bila nilai $\mathrm{t}$ statistik/t hitung setiap variabel lebih besar dari t tabel, dengan alpha $(\alpha) 5 \%(1.960)$ atau $t_{\text {hitung }}>t$ tabel $(0,05: 8926=1.960)$, maka ada pengaruh atau kontribusi ketiga variabel (pengetahuan, keterampilan, dan sikap) terhadap peningkatan kompetensi guru IPA MTs, atau ketiga variabel tersebut merupakan faktor yang signifikan mempengaruhi peningkatan variabel laten kompetensi. Analisis PLS akan menghasilkan nilai korelasi/pengaruh atau dalam istilah analisis PLS disebut loading faktor. Berikut tabel hasil pengujian terhadap ketiga variabel.

Tabel 1. Pengaruh variabel pengetahuan, keterampilan dan sikap dalam membentuk kompetensi guru IPA MTs alumni diklat

\begin{tabular}{|l|c|c|c|c|}
\hline \multicolumn{1}{|c|}{ Komponen } & $\begin{array}{c}\text { Nilai } \\
\text { kenaikan }\end{array}$ & $\begin{array}{c}\text { Nilai korelasi/ } \\
\text { Pengaruh }\end{array}$ & T $_{\text {Statistik/t }}$ hitung & Keterangan \\
\hline Pengetahuan & 79,49 & 0,921 & 79,76 & Pengaruh signifikan \\
\hline Keterampilan & 78,12 & 0,952 & 133,81 & Pengaruh signifikan \\
\hline Sikap & 83,17 & 0,864 & 46,10 & Pengaruh signifikan \\
\hline
\end{tabular}

Penjelasan terhadap hasil pengujian dengan analisis PLS sebagai berikut:

- Pengujian terhadap variabel pengetahuan, menunjukkan adanya nilai korelasi/kekuatan hubungan antara variabel pengetahuan dengan variabel kompetensi sebesar 0,921, dengant $_{\text {statistik }} / \mathrm{t}_{\text {hitung }} 79,76$ atau $>1,96$. Hasil ini menunjukkan bahwa variabel pengetahuan signifikan mempengaruhi terhadap variabel kompetensi, sehingga setiap peningkatan kompetensi guru ada peran dari variabel pengetahuan tersebut.

- Pengujian terhadap variabel keterampilan, juga menunjukkan adanya nilai korelasi dengan variabel kompetensi sebesar 0,952, dengan $\mathrm{t}_{\text {statistik }} / \mathrm{t}_{\text {hitung }} 133,81$ atau $>1,96$. Ini berarti variabel keterampilan juga signifikan mempengaruhi variabel kompetensi, dan setiap peningkatan kompetensi guru ada peran dari variabel keterampilan.

- Pengujian terhadap variabel sikap, juga menunjukkan adanya nilai korelasi dengan variabel kompetensi sebesar 0,864, dengan t

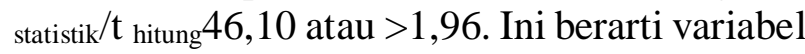

sikap juga signifikan mempengaruhi variabel kompetensi, dansetiap peningkatan kompetensi guru juga ada peran dari variabel sikap.

Hasil pengujian terhadap ketiga variabel (pengetahuan, keterampilan dan sikap) menunjukkan adanya pengaruh/kontribusi signifikan terhadap peningkatan kompetensi guru IPA MTs. Hasil ini berarti jika pemerintah ingin membuat kebijakan untuk meningkatkan kompetensi guru IPA MTS, maka terlebih dahulu harus meningkatkan pengetahuan, keterampilan, dan sikap guru dalam pembelajaran, dan melihat prioritas mana yang perlu ditingkatkan dari ketiga variabel tersebut.

Untuk mengetahui adanya hubungan antar variabel, juga dilakukan analisis antar tiga variabel, seperti variabel pengetahuan dengan keterampilan dan sikap. Asumsinya, proses diklat dimulai dari pengetahuan. Ada proses perpindahan pengetahuan dari Widyaiswara ke peserta diklat. Sehingga semakin tinggi pengetahuan yang diperoleh guru IPA dalam diklat, maka semakin meningkat keterampilan dan sikapnya. Karena diklat sesungguhnya 
adalah proses pembelajaran dari Widyaiswara kepada peserta diklat. Dari tiga komponen pembentuk kompetensi tersebut, pengetahuan merupakan komponen dasar, sehingga seorang guru IPA MTs akan mempunyai sikap dan keterampilan yang baik, diawali oleh seberapa baik pengetahuan yang dimiliki.

Hasil analisis menunjukkan ada korelasi antara pengetahuan dan sikap sebesar 0,286. Ini berarti setiap peningkatan pengetahuan guru, maka akan meningkatkan sikapnya sebesar $\left(0,286^{2} \times 100 \%=47,20 \%\right)$.

Dengan meningkatnya pengetahuan guru IPA MTs dalam proses diklat tersebut, maka ada kecenderungan akan meningkatkan sikapnya dalam mengajar menjadi lebih baik. Sikap guru yang mencakup kejujuran, kedisiplinan, keikhlasan, dan kemauan mempertahankan semangat mengajar ini akan terdorong, ketika guru memiliki pengetahuan yang baik dalam hal pembelajaran.
Hasil analisis juga menunjukkan, ada korelasi antara pengetahuan dengan keterampilan sebesar 0,859. Dengan meningkatnya pengetahuan guru IPA MTs dalam proses diklat tersebut, juga akan meningkatkan keterampilannya sebesar $\left(0,859^{2} \times 100 \%=73,79 \%\right)$. Keterampilan guru yang mencakup kemampuan mengidentifikasi dan mengenal karakteristik siswa, kemampuan menjelaskan materi IPA, kemampuan mengembangkan metode pembelajaran, menciptakan suasana belajar yang menyenangkan, memanfaatkan media pembelajaran, dan melakukan evaluasi hasil pembelajaran, juga akan meningkat apabila guru memiliki pengetahuan yang baik. Hasil analisis juga menunjukkan adanya korelasi antara keterampilan dengan sikap sebesar 0,467. Ini berarti peningkatan keterampilan guru IPA MTs, juga mampu mendorong peningkatan sikapnya dalam mengajar, namun kontribusinya sangat kecil/tidak signifikan yakni sebesar $\left(0,467^{2} \times 100 \%=21,81 \%\right)$.

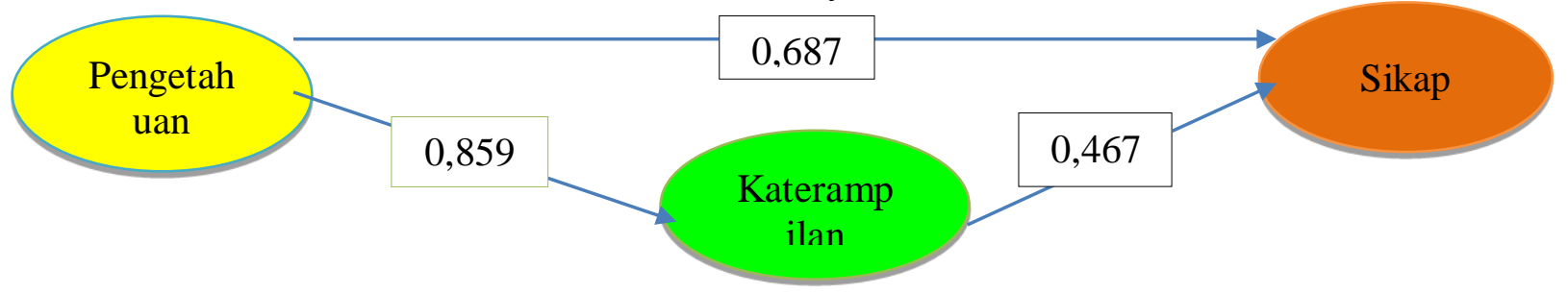

Gambar 1. Diagram jalur hubungan pengetahuan, keterampilan dan sikap

Gambar ini menunjukkan bahwa pengetahuan menjadi variabel utama yang secara langsung mendorong peningkatan kompetensi sikap dan keterampilan, dan melalui peningkatan keterampilan juga mendorong peningkatan kompetensi sikap. Dengan demikian, variabel keterampilan disamping merupakan variabel yang secara langsung mendorong peningkatan kompetensi sikap, tetapi juga menjadi variabel intervening antara variabel pengetahuan dan dikap.

Disamping melakukan analisis antar variabel, juga dilakukan analisis antara identitas dengan kompetensi. Tujuan pengujian ini adalah untuk melihat apakah identitas responden guru IPA MTs seperti jenis kelamin, usia, pendidikan, status kepegawaian, frekuensi mengikuti diklat, lama waktu diklat dan tempat diklat, juga mempunyai pengaruh terhadap kompetensi. Asumsi yang dibangun adalah apabila ada perbedaan atau pengaruh dari variabel identitas, maka persepsi peningkatan kompetensi yang dirasakan guru IPA MTs berbeda antara beberapa jenis identitas tersebut.

Dari pengujian statistik antara identitas dengan kompetensi menunjukkan bahwa tingkat signifikansinya $(\mathrm{P}>0,05)$ untuk semua variabel identitas.Ini artinya identitas responden tidak berpengaruh signifikan terhadap peningkatan kompetensi, sehingga peningkatan kompetensi guru IPA baik variabel pengetahuan, sikap dan keterampilan, tidak ditentukan/dipengaruhi oleh perbedaan jenis kelamin, usia, jenjang pendidikan, status kepegawaian, frekuensi mengikuti diklat dan tempat mengikuti diklat. Hasil pengujian yang tidak signifikan ini berarti bahwa proses diklat sudah berjalan dengan baik, dan proses pengajaran sudah merata untuk semua jenis identitas responden, sehingga tidak perlu ada 
perlakuan khusus oleh widyaiswara terhadap peserta diklat tertentu. Hal ini dipersepsikan oleh peserta diklat bahwa jenis identitas seperti jenis kelamin, usia, pendidikan, frekuensi ikut diklat dan tempat diklat, tidak mempengaruhi peningkatan kompetensi guru IPA MTs, karena seluruhnya memiliki nilai pengaruh yang sangat kecil di bawah $2 \%$. Lihat gambar berikut.

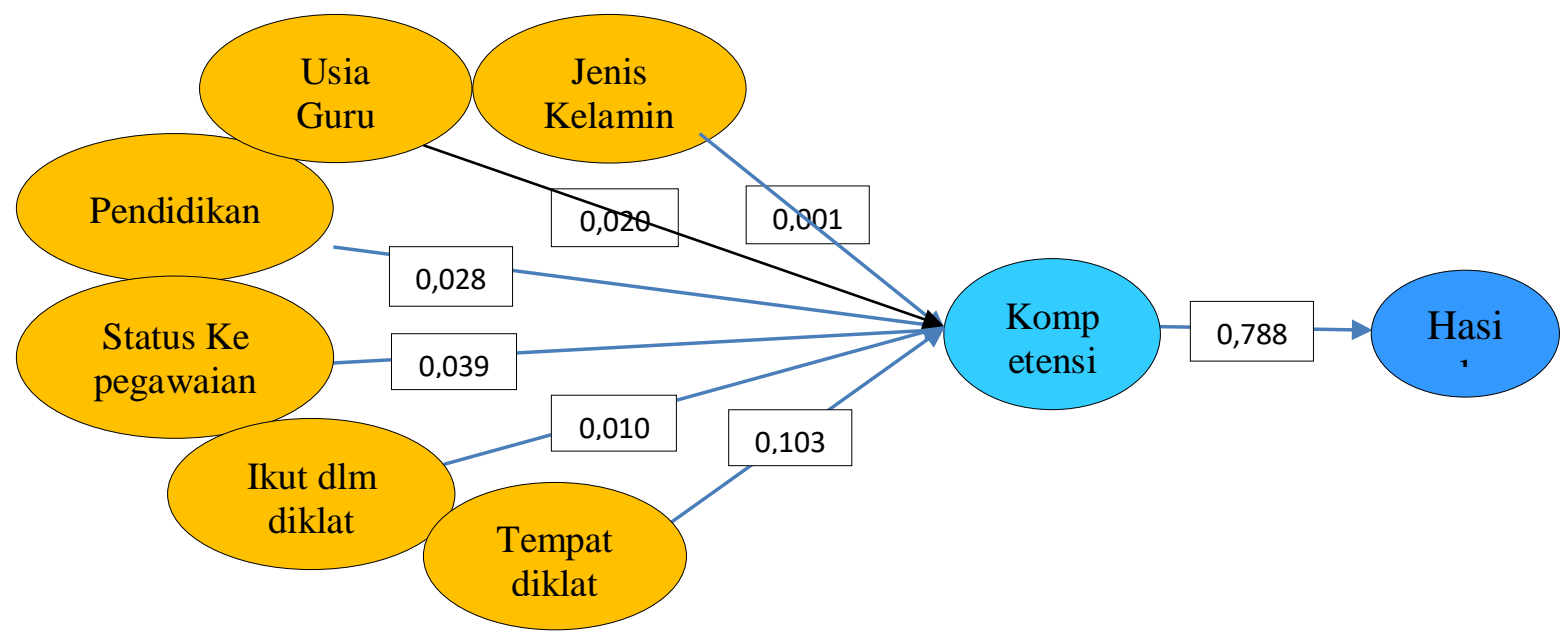

Gambar 2. Pengaruh identitas terhadap kompetensi

\section{Dampak Diklat Terhadap Perilaku Guru IPA MTs}

Skor peningkatan perilaku guru setelah mengikuti diklat yang diukur melalui 6 indikator adalah sebesar 82,00, dengan rentang peningkatan perilaku berkisar antara 79-84. Indikator paling tertinggi peningkatannya adalah loyalitas guru terhadap pekerjaan, semangat kerja dan rasa tanggung jawab. Sedangkan indikator yang terendah adalah kecepatan kerja.

Kondisi tersebut menunjukkan bahwa pelaksanaan diklat teknis bagi guru IPA MTs ini telah berdampak pada peningkatan perilaku guru dalam mengajar terutama pada aspek loyalitas, semangat dan tanggung jawabnya. Meningkatnya perilaku guru ini berarti diklat telah memberi manfaat lain bagi guru selain meningkatkan pengetahuan, keterampilan dan sikap, juga meningkatkan perilaku. ini sesuai dengan Perkalan Nomor 3 Tahun 2010, bahwa diklat teknis dilaksanakan untuk mencapai persyaratan kompetensi teknis yang diperlukan bagi pelaksanaan tugas Pegawai Negeri Sipil (PNS) dalam bidang tertentu, diklat teknis memiliki tujuan untuk meningkatkan pengetahuan, keahlian, keterampilan dan sikap, untuk dapat melaksanakan tugas jabatan teknis secara profesional dengan dilandasi kepribadian dan etika PNS dengan kebutuhan instansi, serta untuk memantapkan sikap, perilaku dan semangat pengabdian, yang berorientasi pada pelayanan, pengayoman dan pemberdayaan masyarakat. Menurut Rafles Tiara Sakti (2015), ada beberapa manfaat diklat bagi pegawai antara lain: a) mampu meningkatkan cara kerja pegawai yang lebih statis, b) mampu meningkatkan volume kerja, c) mampu meingkatkan pekerjaan yang lebih efisien, d) pegawai mampu melaksanakan tugas dengan baik, dan e) meningkatkan semangat kerja pegawai.

Meningkatnya perilaku guru ini, berarti program diklat sebagai proses pembelajaran, juga mendorong pegawai memiliki perilaku yang lebih baik. Menurut Saleem dan Mehwish (2011) pelatihan adalah sebuah program meningkatkan kinerja pegawai yang terorganisir dan sistematis dari kemampuan yang hanya tahu tentang bagaimana menjadi kemampuan yang implementatif yang bisa melakukan eksekusi pekerjaan secara efisien.

\section{Analisis Data Keberhasilan Penyelenggaraan Diklat}

Penyelenggaraan diklat yang diukur melalui 18 indikator yaitu: kesesuaian materi diklat dengan (kebutuhan peserta diklat, kebutuhan dalam mengajar, dan dengan silabus mapel); penyampaian materi diklat fokus pada konsep pembelajaran IPA dan pengembangan keterampilan guru dalam pembelajaran praktikum; ketersediaan sumber, media dan alat belajar dalam diklat yang lengkap jenis dan 
jumlahnya serta sesuai dengan kebutuhan diklat; ketersediaan media audio dan visual serta sarana laboratorium IPA; ketersediaan perpustakaan yang nyaman dan strategis serta dilengkapi bahan pustaka yang lengkap jumlah dan jenisnya, ketersediaan widyaiswara yang memiliki (kompetensi yang baik, kualifikasi $\geq \mathrm{S} 2$ dan tidak mismatch) untuk mapel fisika, kimia dan biologi; dan seluruhnya merupakan pegawai Kemenag, hasilnya menunjukkan bahwa keberhasilan penyelenggaraan diklat mencapai $78,22 \%$, atau masuk kategori baik/tinggi, dengan rentang rata-rata antara 40-99\%. Ini artinya penyelenggaraan diklat teknis guru IPA MTs secara umum sudah baik, namun belum maksimal, karena masih ada kelemahan pada 4 indikator, yaitu belum tersedianya laboratorium IPA memadai pada seluruh BDK dengan bahan dan alat praktikum yang lengkap jenis dan jumlahnya; belum tersedianya perpustakaan yang nyaman, strategis, dan bahan pustaka yang lengkap jumlah dan jenisnya.

Kondisi ini juga disampaikan oleh beberapa guru IPA alumni diklat di wilayah BDK Surabaya, Jawa Barat, dan Denpasar (2016), bahwa kelemahan penyelenggaraan diklat teknis guru IPA adalah belum tersedianya laboratorium IPA yang memadai, sehingga dalam penyelenggaraan diklat masih fokus pada pembelajaran teori di kelas dan sangat minim praktikum. Untuk kebutuhan pembelajaran praktikum, umumnya dilakukan saat kegiatan Orientasi Lapangan (OL) melalui kerjasama dengan MTs yang ada di sekitar BDK. Namun pemilihan MTs sebagai tempat OL kurang tepat, karena MTs yang dipilih rata-rata tidak memiliki laboratorium yang representatif untuk kegiatan praktikum, akibatnya kegiatan praktikum hanya dilakukan seperti main-main dan tidak serius. Melihat kondisi ini, para guru IPA alumni diklat menyarankan sebaiknya BDK segera menyediakan laboratorium IPA yang representatif sebagai pusat kegiatan praktikum bagi peserta diklat mapel IPA, atau bekerjasama dengan lembaga-lembaga riset yang memiliki sarana laboratorium yang lengkap, agar para guru dalam mengikuti diklat memperoleh bekal pengetahuan dan keterampilan yang memadai. Menurut mereka bahwa pembelajaran IPA tidak akan lengkap tanpa dibarengi kegiatan praktik. Kekurangan lainnya adalah belum tersedianya perpustakaan yang nyaman dan berbasis IT (Electronic Library) di BDK sebagai pusat belajar, yang dilengkapi dengan bahan pustaka yang beranekaragam jenis dan jumlahnya. Perpustakaan bagi peserta diklat merupakan sarana yang sangat dibutuhkan terutama saat mengerjakan tugas, perlu ketersediaan sumber belajar dengan pelayanan yang cepat dan berbasis IT.

Pada komponen widyaiswara, meskipun sebagian besar sudah memiliki kompetensi yang baik dan kualifikasi pendidikan $\geq \mathrm{S} 2$ serta tidak mismatch, namun juga masih ada kekurangannya seperti masih ada beberapa widyaiswara yang tidak mampu memecahkan persoalan ketika praktik lapangan. Sementara pada komponen penyelenggaraan diklat, kelemahannya terjadi dalam menetapkan waktu diklat yang terlalu pendek (antara satu sampai dua minggu), yang dibagi untuk jam pelajaran penunjang yang durasi waktunya lumayan banyak, sehingga waktu diklat untuk materi IPA menjadi terkurangi, bahkan pembagian jam pelajaran untuk kegiatan pembelajaran kelas dan praktikum yang tidak seimbang atau bahkan hampir tidak tersedia jam pelajaran kegiatan praktikum.

Terlepas dari segala kelebihan dan kekurangannya, secara umum penyelenggaraan diklat teknis bagi guru IPA MTs memiliki manfaat yang besar bagi peningkatan pengetahuan, keterampilan, dan sikap guru dalam mengajar. Oleh karena itu ke depan perlu ditingkatkan lagi penyelenggaraan diklat semacam ini dengan frekuensi kegiatan yang lebih banyak dan dilaksanakan secara kontinu setiap tahun, dengan jumlah peserta yang lebih banyak dan merata pada seluruh guru IPA di MTs.

\section{Peningkatan Kompetensi Guru Pasca Diklat (Evaluasi oleh Kepala Madrasah)}

Hasil pengukuran melalui tiga variabel (pengetahuan, keterampilan dan sikap), menunjukkan bahwa kompetensi guru IPA MTs setelah mengikuti diklat mengalami peningkatan yang signifikan. Dari tiga variabel tersebut, variabel sikap merupakan variabel tertinggi dalam mendukung peningkatan kompetensi guru IPA setelah mengikuti diklat, 
disusul variabel pengetahuan dan keterampilan. Hasil ini menunjukkan bahwa kepala madrasah menilai diklat teknis yang diselenggarakan di Pusdiklat dan BDK mempunyai peranan yang sangat penting dalam mendorong peningkatan kompetensi guru sebesar 82,23 dan masuk kategori tinggi. Dari tiga variabel tersebut, variabel sikap merupakan variabel tertinggi dalam mendukung peningkatan kompetensi guru dengan skor 83,29 , disusul variabel pengetahuan skor 82,94 dan variabel keterampilan dengan skor 80,46.

\section{Peningkatan Kompetensi Guru IPA MTs Pasca Diklat (Evaluasi Oleh Guru IPA Teman Sejawat)}

Hasil pengukuran yang dilakukan oleh teman sejawat juga dilakukan melalui tiga variabel, menunjukkan bahwa kompetensi guru IPA MTs setelah mengikuti diklat, juga mengalami peningkatan yang signifikan. Dari tiga variabel tersebut, variabel sikap merupakan variabel tertinggi dalam mendukung peningkatan kompetensi guru IPA, disusul variabel pengetahuan dan keterampilan. Hasil ini menunjukkan bahwa guru IPA teman sejawat juga menilai diklat teknis yang diselenggarakan ini mempunyai peran penting

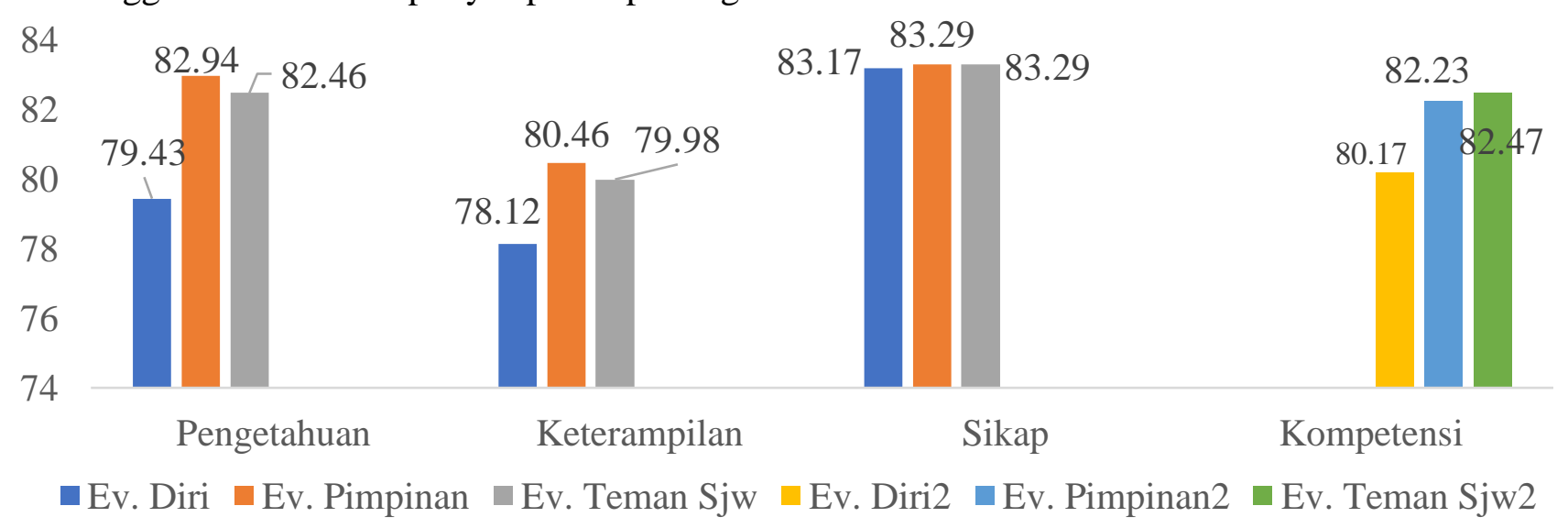

Gambar 3. Komparasi kompetensi guru IPA MTs

Dengan melihat capaian skor hasil olah data penelitian Evaluasi Implementasi Hasil Diklat Teknis Guru IPA MTs, terlihat bahwa guru IPA MTS yang pernah mengikuti diklat meningkat kompetensinya dan mampu mengimplementasikan hasil diklat dalam kegiatan pembelajaran dengan baik. Adanya peningkatan kompetensi ini, sehingga penyelenggaraan pembelajaran menjadi lebih baik, karena guru telah mengalami peningkatan kompetensi yang signifikan terutama pada dalam peningkatan kompetensi guru sebesar 82.47 dan masuk kategori tinggi. Dari tiga variabel tersebut, variabel sikap merupakan variabel tertinggi dalam mendukung peningkatan kompetensi guru IPA dengan skor 83,29 , disusul variabel pengetahuan dengan skor 82,46 dan variabel keterampilan dengan skor 79,98 .

\section{Komparasi Peningkatan Kompetensi Guru IPA MTs Setelah Mengikuti Diklat}

Hasil analisis menunjukkan bahwa secara umum penyelenggaraan diklat teknis bagi guru mapel IPA di MTs sudah sangat baik, dilihat dari capaian peningkatan kompetensi guru IPA MTs setelah mengikuti diklat sangat tinggi, baik dari persepsi guru IPA MTs itu sendiri, persepsi Kepala/Wakil Kepala MTs dan persepsi guru teman sejawat, dengan persentase peningkatan sebesar $80 \%$. Variabel sikap, paling tinggi kenaikannya dibanding dua variabel lainnya yaitu pengetahuan dan keterampilan. Sedangkan dilihat dari penilaian responden, Kepala/Wakil Kepala MTs dan teman sejawat, menilai lebih tinggi dibandingkan guru IPA MTs itu sendiri (Gambar 3).

aspek pengetahuan, keterampilan dan sikap. Hal ini dipertegas oleh para guru IPA MTs alumni diklat yang ada di 6 wilayah BDK yaitu Jawa Timur, Jawa Barat, Denpasar, Banten, Jawa Tengah dan Palembang (2016), bahwa setelah mengikuti diklat mereka merasa banyak memperoleh peningkatan pengetahuan, keterampilan dan sikap, serta mampu mengimplementasikannya dalam pembelajaran. Menurut mereka, diklat yang telah diikutinya mampu meningkatkan kompetensinya secara 
signifikan, karena tema-tema diklat yang diajarkan sebagian merupakan hal baru bagi mereka, dan sebagian merupakan pendalaman terhadap materi IPA. Peningkatan kompetensi yang mereka rasakan antara lain:

- Peningkatan pada aspek pengetahuan seperti: 1) memiliki pengetahuan yang lebih luas terhadap materi ajar dan strategi serta metode pembelajaran, sehingga mampu menyelenggarakan pembelajaran IPA yang menarik, menyenangkan dan tidak membosankan, 2) memiliki pengetahuan dalam pengelolaan kelas lebih baik sehingga dapat meminimalisir gangguan dan mengelola situasi pembelajaran yang lebih tenang, 4) memiliki pengetahuan dalam pengelolaan siswa, sehingga lebih mengetahui cara mengenal karakteristik, potensi, bakat dan minat belajar siswa, lebih mengetahui cara memotivasi, membimbing, dan membangun sikap disiplin, jujur dan tanggung jawab siswa.

- Peningkatan pada aspek keterampilan seperti lebih terampil dalam hal: 1) menerapkan strategi yang tepat, bervariasi dan berbasis IT dalam pembelajaran IPA, 2) membuat media belajar IPA dengan memanfaatkan barang bekas dan lingkungan alam sekitar, 3) membimbing siswa dalam belajar kelompok praktik di laboratorium; menyusun laporan hasil belajar praktik, dan diskusi kelompok.

- Peningkatan pada aspek sikap seperti:1) sikap terhadap diri sendiri yaitu: lebih rajin, disiplin, tepat waktu, dan tanggung jawab dalam melaksanakan tugas; lebih percaya diri dalam melaksanakan pembelajaran; lebih semangat mengajar; dan termotivasi meningkatkan capaian hasil belajar siswa, 2) sikap dalam pembelajaran yaitu: lebih kreatif dan inovatif mengembangkan media pembelajaran, mengelola kelas dan menciptakan suasana pembelajaran yang menyenangkan; lebih semangat meningkatkan kompetensi, dan lebih profesional dalam mengajar, 3) sikap terhadap siswa yaitu: lebih sabar membimbing siswa dalam belajar dan lebih menyayangi siswa, karena memahami potensi, kelebihan dan kekurangannya.

Menurut para guru IPA MTs alumni diklat di 6 wilayah tersebut, peningkatan kompetensi yang diperoleh melalui diklat ini dapat terimplementasi dengan baik dalam proses pembelajaran. Namun untuk pembelajaran praktik di laboratorium masih terdapat kendala seperti: 1) sekitar 26\% madrasah sasaran evaluasi belum memiliki laboratorium, sementara sejumlah madrasah yang sudah memiliki laboratorium, sebagian kondisinya kurang bahkan tidak layak, sehingga ilmu yang diperoleh dalam diklat tidak dapat diimplementasikan dalam kegiatan praktik, 2) adanya kebijakan madrasah yang salah dengan menyulap ruang laboratorium menjadi ruang kelas untuk menutupi kekurangan ruang belajar, sebagaimana yang terjadi di beberapa madrasah di Karawang, Bandung Barat, Jombang, Nganjuk, Madiun, Ngawi, (observasi peneliti, 2018); 3) masih banyak guru IPA belum memiliki kemampuan melakukan pembelajaran praktik di laboratorium, karena belum pernah memperoleh diklat, terutama guru di madrasah swasta yang ada di pelosok pedesaan dan di wilayah perbatasan.

Kenyataan ini menggambarkan bahwa capaian skor kompetensi yang tinggi bagi guru IPA MTs alumni diklat belum berbanding lurus dengan capaian hasil belajar di madrasah. Meskipun secara umum guru IPA alumni diklat memperoleh skor sangat tinggi terkait peningkatan kompetensi dan kemampuan mengimplementasikan dalam pembelajaran, namun itu bersifat individu-individu dan belum didukung oleh keseluruhan komponen madrasah seperti dukungan kebijakan kepala madrasah, dukungan teman seprofesi; dan dukungan sarana prasarana. Sehingga peningkatan kompetensi guru IPA alumni diklat tersebut belum berdampak signifikan dalam meningkatkan capaian hasil belajar siswa. Dengan kata lain, dampak diklat baru dirasakan oleh segelintir guru IPA alumni diklat saja.

.Fakta di lapangan menunjukkan, dari hasil pelaksanaan evaluasi terhadap guru mapel IPA MTs tahun 2018, bahwa dalam satu kabupaten/kota rata-rata hanya ditemukan sekitar 1-4 orang guru IPA MTs alumni diklat tahun 2014-2017, bahkan banyak kabupaten/kota yang sama sekali tidak ditemukan guru IPA MTs alumni diklat tersebut, padahal jumlah guru IPA MTs sangat banyak mencapai ratusan. 
Belum meratanya jangkauan peserta diklat ini juga disebabkan oleh banyak faktor antara lain: 1) rekrutmen peserta diklat yang kurang tepat dan terkesan sekenanya, karena tidak mengedepankan pada keterpenuhan kriteria/persyaratan teknis dan administratif, 2) program diklat terhadap mapel IPA belum bersifat longitudinal (multiyears), 3) beberapa BDK hanya menyelenggarakan satu kali kegiatan dalam setahun dengan jumlah peserta 35 orang seperti BDK Surabaya, Denpasar, dan Semarang, bahkan beberapa BDK ada yang sama sekali tidak menyelenggarakan, 4) jumlah kantor BDK yang terbatas, sehingga satu BDK ada yang memiliki wilayah kerja hingga 4 provinsi, dll.

Beberapa faktor tersebut, menyebabkan diklat teknis guru mapel IPA MTs baru dapat dinikmati oleh segelintir guru dan belum merata pada seluruh guru IPA MTs baik yang negeri atau swasta, serta yang di perkotaan maupun pedesaan, sehingga diklat belum berdampak signifikan meningkatkan mutu pembelajaran IPA pada MTs. Padahal salah satu tujuan diklat adalah untuk memenuhi kebutuhan instansi terhadap keberadaan pegawai yang memiliki kemampuan dan keterampilan yang baik (PP Nomor 101 tahun 2000). Menurut B. Suryosubroto (2004), bahwa diklat merupakan kegiatan pendidikan pegawai atau calon pegawai yang berkaitan dengan usaha peningkatan pengetahuan, keterampilan dan sikap, guna pencapaian tujuan organisasi yang efektif dan efisien.

Belum meratanya jangkauan peserta diklat dan terbatasnya frekuensi kegiatan diklat teknis guru mapel IPA ini, di satu sisi menjadikan kebutuhan instansi (kemenag) akan pegawai (guru IPA MTs) yang kompeten menjadi sulit tercapai, dan disisi lain banyak guru IPA yang hingga saat ini belum tersentuh kegiatan diklat. Padahal pernah disusun program capaian diklat teknis bagi guru 4 tahun sekali, dengan tujuan untuk memperbanyak frekuensi diklat agar setiap guru memperoleh diklat minimal 4 tahun sekali. Namun kenyataannya program tersebut masih sulit direalisasikan, padahal diklat sebagai wahana pengembangan kompetensi dan merupakan hak setiap pegawai (LAN, 2018). Melihat banyaknya keterbatasan dalam penyelenggaraan diklat sebagaimana diuraikan, sehingga dampak diklat belum maksimal dapat dirasakan oleh madrasah.

\section{PENUTUP}

Evaluasi implementasi hasil diklat teknis bagi guru IPA MTs yang dilakukan tahun 2018 oleh Puslitbang Pendidikan Agama dan Keagamaan, hasilnya menunjukkan bahwa setelah mengikuti diklat guru mengalami peningkatan kompetensi sangat tinggi dengan memperoleh skor di atas 80. Umumnya para guru merasakan setelah mengikuti diklat, ada peningkatan kompetensi pada aspek pengetahuan, keterampilan dan sikap. Namun demikian, hasil diklat yang bagus ini belum berdampak signifikan dalam meningkatkan mutu madrasah, disebabkan sulitnya mengimplementasikan hasil diklat tersebut karena terkendala oleh kemampuan guru IPA yang belum merata, sarana laboratorium yang belum tersedia di sebagian besar madrasah, masih banyak guru IPA yang belum pernah memperoleh diklat, dan kebijakan madrasah yang tidak/belum mendukung pembelajaran praktikum IPA di laboratorium.

Hasil evaluasi juga menunjukkan bahwa penyelenggaraan diklat masih menuai beberapa persoalan, antara lain: 1) rekrutmen peserta belum tepat, 2) jumlah peserta diklat sangat terbatas, 3) frekuensi diklat terbatas, 4) pelaksanaan diklat belum didukung fasilitas yang memadai, 5) pelaksanaan diklat masih fokus pada pembelajaran teori dan belum berbasis praktik laboratorium, 6) pelaksanaan diklat belum melibatkan unsur/pihak lain terkait. Oleh karena itu direkomendasikan kepada: (a) kemenag, sebaiknya: 1) menyusun program bantuan pengadaan laboratorium IPA bagi MTs lengkap dengan peralatan yang dibutuhkan, 2) membangun BDK di seluruh provinsi, agar penyelenggaraan diklat mampu menjangkau peserta lebih banyak; (b) Pusdiklat dan BDK sebaiknya: 1) Melakukan perbaikan sistem penyelenggaraan diklat yang lebih sistemik dan terstruktur; 2) Menyelenggarakan program diklat teknis guru IPA bersifat multyyears, dan memperbanyak volumenya melalui DDTK, dengan melibatkan banyak partner seperti perguruan tinggi, LPMP, lembaga riset; dengan memperbaiki waktu penyelenggaraannya yang lebih panjang; 3) 
Melakukan rekrutmen calon peserta diklat sesuai dengan kriteria yang ditentukan; 4) Melakukan diklat/TOT calon instruktur tingkat nasional, wilayah dan daerah, agar mampu membantu pelaksanaan diklat melalui DDTK; 5) Menyediakan sarana laboratorium IPA dan perpustakaan yang representatif dan mendukung kegiatan pelatihan; (c) kepada guru alumni diklat, sebaiknya ilmu yang sudah diperoleh melalui diklat diimbaskan kepada guru IPA lainnya, agar kompetensi guru IPA merata di setiap madrasah.

\section{UCAPAN TERIMAKASIH}

Disadari bahwa lancarnya kegiatan penelitian ini tidak lepas dari peran beberapa pihak. Untuk itu saya selaku penulis mengucapkan terima kasih kepada: Kapuslitbang Pendidikan Agama dan Keagamaan yang telah memberikan bimbingan dan pengarahan; teman-teman peneliti yang telah membantu dalam pembahasan dan penyempurnaan desain dan instrumen penelitian; para pembantu lapangan, responden dan narasumber yang telah membantu kelancaran pengumpulan data.

\section{DAFTAR PUSTAKA}

Arikunto, S., Abdul Jabar, S., dan Cepi (2009) Evaluasi Program Pendidikan: Pedoman Teoritis Praktis Bagi Mahasiswa dan Praktisi Pendidikan. Jakarta: Bumi Aksara, Cetakan Ketiga.

Athiyah, C. U. (2019) 'Evaluasi Program Unggulan Pusdiklat Tenaga Teknis Pendidikan dan Keagamaan 2018', EDUKASI: Jurnal Penelitian Pendidikan Agama dan Keagamaan, 17(1). doi: 10.32729/edukasi.v17i1.585

Azaly Al-Farozi, D. (2014) dalam makalahnya berjudul "Evaluasi Kegiatan Diklat" yang disusun untuk memenuhi tugasmata kuliah "Manajemen Program Pendidikan dan Pelatihan" di Fakultas Ilmu Tarbiyah dan Keguruan Universitas Islam Negeri Walisongo Semarang.

Agostiono (2010) Implementasi Kebijakan Publik Model Van Meter dan Van Horn. Available http//kertyawitaradya.wordpre ss, diakses 5 September 2010

Akib, H. (2010) Implementasi Kebijakan: Apa, Mengapa, dan Bagaimana. Jurnal Administrasi Publik Vol. 1, No. 1.

Azwar, S. (2011). Sikap manusia: Teori dan Pengukuran. Jakarta: Pustaka Pelajar

Danim, S. (2002) Inovasi Pendidikan: Dalam Upaya Meningkatkan Profesionalisme Tenaga Kependidikan. Bandung: Pustaka Setia.

Eva, R. (2014) Efektivitas Diklat Berjenjangtingkat Dasar Pendidik Dan Tenaga Kependidikan Paud. JURNAL PENDIDIKAN USIA DINI Volume 8 Edisi 1, April 2014

Hadi (2011) Metode Riset Evaluasi. Jakarta: Rineka Cipta

Hanun, F. (2018) 'Evaluasi Penyelenggaraan Diklat di Kementerian Agama', EDUKASI: Jurnal Penelitian Pendidikan Agama dan Keagamaan, 16(2). doi: 10.32729/edukasi.v16i2.477

Haris Pito, A (2017) dalam artikelnya berjudul "Analisis Permasalahan Diklat Dan Solusinya". Available at: Https://Harispito.Wordpress.Com/2017/0 1/05/47/. (Accessed: 11 Maret 2018)

Hendriani, S. dan A. Nulhaqim, S. (2008) Pengaruh Pelatihan dan Pembinaan Dalam Menumbuhkan Jiwa Wirausaha Mitra Binaan PT. (Persero) Pelabuhan Indonesia I Cabang Dumai

Ismail, I. (2010) Manajemen Sumber Daya Manusia. Malang: Lembaga Penerbitan.

Indonesia (2003) Undang-Undang Nomor 20 Tahun 2003 tentang Sistem Pendidikan Nasional

Indonesia (2005) Undang-Undang Nomor 14 Tahun 2005 Tentang Guru dan Dosen

Keban Yeremias, T. (2008) Enam Dimensi Administrasi Publik: Konsep, Teori dan Isu. Yogyakarta: Gava Media

Lembaga Administrasi Negara (2010) Perkalan Nomor 3 Tahun 2010 tentang Diklat Teknis 
Kemenag (2012) Peraturan Menteri Agama (PMA) Nomor 4 Tahun 2012 tentang Penyelenggaraan Pendidikan dan Pelatihan Teknis di Lingkungan Kementerian Agama.

Kemenag (2015) Peraturan Menteri Agama (PMA) Nomor 75 Tahun 2015 tentang Penyelenggaraan Pendidikan dan Pelatihan Pegawai pada Kementerian Agama.

Kemenag (2016) Statistik Pendidikan Islam Tahun Pelajaran 2014/2015. Jakarta: Direktorat Jenderal Pendidikan Islam, Kementerian Agama RI Tahun 2016.

Kemenag (2016) Peraturan Menteri Agama (PMA) Nomor 43 Tahun 2016 tentang Sistem Informasi Manajemen Pendidikan dan Pelatihan pada Kementerian Agama.

Kemenag (2016) Data tentang Kompetensi Guru MTs dari Kasubdit Bina Guru dan Tenaga Kependidikan (TK) Direktorat Jenderal Pendidikan Islam, Kementerian Agama RI.

Kemenag (2018) Data Alumni Diklat Teknis Guru MTs dalam Simdiklat Kemenag 2014-2017). Jakarta: Pusdiklat Teknis, Kemenag RI.

Lembaga Administrasi Negara (2018) Peraturan Kepala LAN Nomor 10 Tahun 2014 tentang Pengembangan Kompetensi ASN

L., Kirkpatrick, D. (1998) Evaluating Training Programs: The Four Levels. San Francisco: Berret-Koehler Publisher, 2 ed. Available at: http://pusdiklatwas.bpkp.go.id/asset/files/ post/a77/ Evaluasi.Diklat.pd. (Accessed: 1 Maret 2018).

Maura, A. (2018) dalam artikelnya berjudul "Fakta Kualitas Guru di Indonesia yang Perlu Anda Ketahui". Available at: https://blog.ruangguru.com/faktakualitas-guru-di-indonesia-yang-perluanda-ketahui. (Accessed: 1 May 2018).

Mukhtar dan Yamin, M (2010) Sepuluh kiat Sukses Mengajar di Kelas. Jakarta: Nimas Multina.
Mulyasa, E (2004), Kurikulum Berbasis Kompetensi (Konsep, Karakteristik dan Implementasi), Bandung: Remaja Rosdakarya

Meutya, I. (2016) dalam artikelnya berjudul "Ketika Esensi Diklat Menguap". Available at: http://nad.bkkbn.go.id/Lists/Artikel/Disp Form.aspx? $\mathrm{ID}=1411$, diakses tanggal 14 April 2018.

Prilianti, R. (2017) 'Evaluasi Penyelenggaraan Diklat Teknis Substantif Multimedia Bagi Guru Madrasah Aliyah Di Balai Diklat Keagamaan Semarang', Andragogi Jurnal Diklat Teknis, 6(1).

Prastowo, A (2011) Panduan Kreatif Membuat Bahan Ajar Inovatif. Yogjakarta: DIVA Press.

Qowaid, Q. (2012) 'Evaluasi Diklat Jarak Jauh Pada Balai Diklat Keagamaan Semarang', EDUKASI: Jurnal Penelitian Pendidikan Agama dan Keagamaan, 10(3). doi: 10.32729/edukasi.v10i3.166

Qowaid, Q. and Setianingsih, N. (2017) 'Evaluasi Diklat Guru Pendidikan Agama Islam Tingkat SMA', EDUKASI: Jurnal Penelitian Pendidikan Agama dan Keagamaan, 4(4). doi: 10.32729/edukasi.v4i4.146.

Rohman, D. F., Hanafi, I. and Minto, H. (2010) 'Implementasi Kebijakan Pelayanan Administrasi Kependudukan Terpadu (Studi pada Dinas Kependudukan dan Catatan Sipil Kota Malang)', Jurnal Administrasi Publik (JAP), 1(5), pp. 962 971

Sanjaya, W. (2009) Strategi Pembelajaran Berorientasi Standar Proses Pendidikan. Jakarta: Kencana Prenada Media Group.

Sesneg (2000) Peraturan Pemerintah Nomor 101 tahun 2000 Tentang Pendidikan Dan Pelatihan Jabatan Pegawai Negeri Sipil.

Sesneg (2008) Peraturan Pemerintah Nomor 19 Tahun 2017 Tentang Perubahan Atas Peraturan Pemerintah Nomor 74 Tahun 2008 Tentang Guru 
Suprapto, T. (2009) Pengantar Teori \& Manajemen Komunikasi. Yogyakarta: MedPress, Cet.8.

Sudjana, N. (2011) Penilaian Hasil Proses Belajar Mengajar. Bandung: Remaja Rosdakarya

Sukardi (2014) Evaluasi Program Pendidikan dan Pelatihan. Jakarta: Bumi Aksara.

Sujana, N. (2010) Penilaian Hasil Proses Belajar Mengajar. Bandung: PT. Rameja Rosdakarya

Sardiman. (2011) Interaksi dan Motivasi Belajar Mengajar. Available at: http://www.

alhassanain.com/indonesian/articles/artic les/Philosophy_and_gratitude_library/def inisi_pengetahuan/001.html. (Accessed: 9 Maret 2018).

Tiara, S. R. (2015) 'Pelaksanaan Pendidikan dan Pelatihan dalam Meningkatkan Kinerja Pegawai Negeri Sipil PNS) di
Dinas Pendidikan dan kebudayaan Provinsi Bengkulu', Mimbar, 4(2).

Turney (1973) Available at: https://asepfirman17.wordpress.com/adm inistrasi-pendidikan/8-keterampilandasar-mengajar-yang-harus-di. (Accessed: 9 Maret 2018).

Wijaya, A. dan Sumarno, (2017) 'Evaluasi Dampak Pendidikan Dan Pelatihan Pengembangan Keprofesian Berkelanjutan Guru Matematika Di Pppptk Matematika Yogyakarta', Jurnal Penelitian dan Evaluasi Pendidikan, 21(2).

Yasri, Y. (2017) 'Evaluasi Pasca Diklat Guru Muda Madrasah Aspek Kompetensi', Andragogi Jurnal Diklat Teknis, 5(2). 